\title{
Küresel Rekabet Dinamikleri Altında Müşteri Taleplerini Karşılama: PVC Masa Örtüsü Sektörü Üzerine Bir İnceleme
}

\section{Alim Fatih KILINÇ ${ }^{1}$ \\ Ceyda LALE SANCAKTAR ${ }^{2}$}

Öz

Yeniliği ve değişimi benimseyen, müşteri odakl kaliteli bir hizmet sunmayı kendine misyon edinmiş işletmeler, rakiplerinin karşısında önemli bir ilerleme kaydetmektedir. Müşterinin ihtiyacına uygun yeni ürünlerin üretilmesi amactyla Ar-ge ve Ür-ge birimlerine öncelik verip yatırımlarını bu birimlere yönlendirmektedir. İsletmelerin sundukları bu yeni ürünler işletmeye satış, karlıllk ve büyüme olarak birçok noktada katma değer sağlamaktadır. Araştırmanın amacı, müşteri talebi üzerine üretilen yeni ürünün müşterinin ihtiyaçlarına uygun hale getirmek için geçirdiği üretim sürecini analiz ederek, işletmeye ve müşteriye ne şekilde katma değer să̆ladığını ortaya koymaktır. Araştırmanın ilk bölümünde ev tekstili sektörüne ilişkin genel bir değerlendirme yapıldıktan sonra, masa örtüsü ürün grubu ve PVC masa örtüsü üretim süreci hakkında bir bilgilendirme yapılmaktadır. İkinci bölümde, müşterinin istekleri doğrultusunda üretilen yeni ürünün üretim süreci vaka analizi yapılarak açıklanmaktadır. Son bölümde yer alan araştırmanın sonucuna göre, ürün farklılaştırması ile beraber müşterinin memnuniyeti sağlanmış, bu durum da işletmeye satış ve müşteri sadakati olarak yansımıştır.
\end{abstract}

Anahtar Kelimeler: Ev tekstili, PVC masa örtüsü, ürün farklılaştırma, rekabet.

Jel Kodlart:L65, M31.

\section{Meeting Customer Demands Under Global Competitive Dynamics: A Review of PVC Tablecloth Sector}

\begin{abstract}
Businesses which have embraced innovation and change and are committed to providing quality customer-focused services, have made significant progress against their competitors. Businesses which want to have a premise in the competitive environment give preference to $R \& D$ and $P \& D$ units and direct their investments to these units in order to produce new products suitable for the customer's needs. These new products offered by the businesses are preferred by the customers and provide added value to the business as sales, profitability and growth. The aim of the research is to analyze how the new product produced on the customer's request is adapted to the needs of the customer and to show how the business and the customer provide added value. After an overview of the home textiles sector in the first part of the research conducted in this framework, information is provided on the tablecloth product group and PVC tablecloth production process. In the second part, the production process of the new product produced in line with the customer's wishes is explained by making case analysis. According to the result of the research in the last section, customer satisfaction has been provided with product differentiation, which is reflected as sales to the business and customer loyalty.
\end{abstract}

Keywords: Home textile, PVC tablecloth, product differentiation, competition.

Jel Codes: L65, M31.

\footnotetext{
${ }^{1}$ Operasyon Müdürü, Sanem Plastik, akilinc@sanemplastik.com ORCID: https://orcid.org/0000-0002-3045-8640

${ }^{2}$ Dr., Pazarlama Personeli, Sanem Plastik, csancaktar@sanemplastik.com

ORCID: https://orcid.org/0000-0002-5789-7686
} 


\section{Giriş}

Ev tekstili ürünleri, tarihin ilk dönemlerinden beri kullanılan ürün grubudur. Yazılı kaynaklarda bu sürecin Mısırlılar ile başladığı belirtilmesine rağmen, Grek ve Roma uygarlıklarında keten masa örtüsü kullanımına dair kanıtlar bulunmaktadır (Pothault, 1997:70).

Günümüzde ev tekstili, tüketicilerin evde rahat yaşamaları için gerekli şartları sağlayan, niş pazarlarda tüketicilerin ihtiyaçlarına ve beklentilerine göre farklılık gösteren bir sektör olma özelliği taşımaktadır (Das, 2010:1-2). Battaniye, yatak örtüsü, masa örtüsü, banyo ve mutfak tekstili, perdeler, tüller, duvar kaplamaları, şilte, yastık ve dekoratif kullanılan elyaflar ev tekstili ürün grubuna girmektedir (Özgür, 2005:6). Bir başka tanıma göre ev tekstili, halı, yer döşemesi, perde, havlu, masa örtüsü, yatak örtüsü, duvar kâğıdı vb. birçok ürün ile sınırlı kalmamakla beraber, teknik tekstilin önemli bir kısmı oluşturmaktadır (Das, 2010:1-2).

Ev tekstili ürün grubu geniş bir ürün çeşitliliği sunarken, bu ürün grubuna günümüzün şartlarına uygun yeni bir sınıflandırma yaklaşımı getirilmiştir. İnsan ve mekân faktörlerine göre bir sınıflandırma yapılmış, insanla doğrudan veya dolaylı ilişkili, mekanla doğrudan veya dolaylı ilişki olmak üzere dört farklı kategoride ürünler toplanmıştır. Ev tekstili ürününün insanla olan ilişkisi teni ile temasın olup olmadığına bağlı iken, mekanla olan ilişkisi ürünün mekâna görsellik yönünde yaptıkları etki ile ilgilidir (Durur ve Parer, 2009:18).

Yeni tasarım konsepti ve yapılan yenilikler, ürüne ait fonksiyonel özelliklerin keşfedilmesi üzerine yapılmaktadır. Fakat günümüzde stil ve renkler tüketicileri etkilemede tek başına yeterli olmamaktadır. Bu nedenle, sofistike tüketicilerini etkilemek için ürünlerin uluslararası yasal ve güvenlik şartlarını karşılaması ve çevre dostu olması gibi işlevsel özellikleri geliştirilmektedir (Das, 2010:1-3). Bununla birlikte, ev tekstili ürünlerinin kullanışlı olma özelliği de büyük önem taşımaktadır. Ürünlerin ebatlarının eşyalar ile uyumlu olması, kullanım ömrü ve bakımı, ürünün sağlığa uygun olması gibi özellikler ev tekstili ürünleri için tüketiciler tarafından aranan özelliklerdir (Taylor, 1972:21).

\section{Literatür Araştırması}

Ev tekstili, tekstil sektöründe en önemli dinamik ürünlerden biri olma özelliği taşımaktadır. Geçmiş yıllardan beri, sektörde önemli ilerlemeler kaydedilmiştir. Bu pazarın gelişimi, fiber kombinasyon, kumaşlar, tasarımlar, dokular ve renkler üzerinde fonksiyonel talebin ve tüketicideki konfor eğiliminin artması ile beraber olmuştur (Das, 2010:2).

Ev tekstili ürünleri, giysilerden daha az satın alınan ürünlerdir ve bu nedenle ürünlerin markalaşması önemsenmeyebilmektedir (Ersoy vd., 2007:13). Fakat düşük bir marka profiline sahip ürünler, müşteri sadakatini sınırlandırmaktadır. Uzun ömürlü iyi kalitede bir ürün, tüketiciye maddi anlamda değer katmaktadır. Ürün kısa vadede daha pahalı olsa bile, iyi kaliteye sahip olmasından dolayı uzun vadede tüketiciye daha uygun fiyata gelebilmektedir (Holmsten, 2013:42,44).

Ev tekstili, düşük maliyetli ve lüks ürünlerden daha çok ihtiyacı duyulan bir ürün profiline sahiptir (Ama Research,2016:3). Ev tekstili için yapılan harcamalar üzerinde, toplam tüketim harcamaları, aile tipi, yaşanan bölge ve şehrin büyüklüğü gibi birçok demografik faktörün etkisi olabilmektedir (Wagner,1986). Bununla birlikte, ev tekstili sektörü çevresel faktörlerden de etkilenebilmektedir. Küresel krizin ve ekonominin ev tekstili ürün grubunu etkilediğine yönelik araştırmalar bulunmaktadır (Kılıç vd., 2011:77, Ozgur, 2005).

Bu noktadan hareketle, ilk olarak dünyada ve Türkiye'de ev tekstili sektörünün durumu incelenecektir. 


\section{Dünyada ve Türkiye’de Ev Tekstili Sektörü}

\subsection{Dünyada Ev Tekstili Sektörü}

Dünyada ev tekstili ticareti y1llık olarak değerlendirildiğinde, küresel ölçekli finansal kriz gibi çeşitli olayların rakamları etkilediği görülmektedir. Kriz süresince tüketiciler, zorunlu olmayan ihtiyaçlarından vazgeçebilmektedir. Örneğin, 2008 yılında ABD'de çıkan finansal kriz, 2009 yılında ev tekstili ticaretini \%16'lık bir oranda daraltmasına neden olmuştur. Kriz sürecinin etkilerinin azalması ile beraber 2010 yılında dünya ev tekstili hacmi yine büyümeye geçmiştir (T.C. Ekonomi Bakanlığı, 2016:3).

Dünyada ev tekstili sektörü ile ilgili yapılan istatistiklerde, bu alanda yapılan ticaretin 2014 yılında toplamda 130 milyar dolar civarında olduğu, 2015 yılı itibari ile 123 milyar dolara düştüğü belirtilmektedir (UİB, 2017:2).

Ev tekstili ihracatında da aynı yıllarda benzer bir düşüşün yaşandığı bilinmektedir. Aşağıda yer alan Tablo 1'de ev tekstili ihracat rakamları incelendiğinde, dünya ev tekstili ihracatının 2014 yılında 72,9 milyar dolar civarında gerçekleştiği ve 2015 yılında 65,6 milyar dolara düştüğü görülmektedir (Trademap, 2017).

İhracat hacmi ev tekstili ürün grubu olarak değerlendirdiğinde sentetik filament ipliklerinden dokunmuş mensucat ürünleri 23,9 milyar dolar ile ilk sırada yer almaktadır. Yatak çarşafları, masa örtüleri, tuvalet ve mutfak bezleri ise 19,6 milyar dolar ile listeyi takip ederken, mefruşat eşyaları 5,6 milyar dolarlık ihracat hacmiyle dünya ev tekstilinde ilk sıralarda bulunmaktadır (UIBB, 2017:2).

Yazında yer alan araştırmalarda Türkiye, Çin ve Pakistan gibi ülkeler, sahip oldukları birkaç şehir ve bölge ile ev tekstili alanında taleplere cevap veren en başarılı ülkelerdendir (Özgür, 2005:3). Tablo 1'de görüldüğü üzere, ev tekstili ihracatında 2015 yılında Çin 31,2 milyar dolarla ilk sırada bulunurken, Çin'i 4,7 milyar dolarla Hindistan, 3,3 milyar dolarla Pakistan takip etmektedir. Türkiye 2,8 milyar dolarla dördüncü sırada yer almaktadır.

Çin'in listede ilk sırada olmasının nedenleri arasında, DTÖ üyesi olarak pazara girmesi ve ucuz işgücü avantajından yararlanması bulunmaktadır. Çin'in ardından büyük paya sahip ülkelerden olan Pakistan ve Hindistan'ın ilk sıralarda olma nedenleri, ucuz işgücü ve hammaddeden kaynaklanmaktadır. Türkiye’deki ev tekstili ise bu ülkelere göre daha kaliteli ürünler ürettiği için tercih edilmektedir (GEKA, 2015:30).

Tablo 1: Dünya Ev Tekstili İhracatında İlk 10 Ülkenin 3 Y1llı İhracat Rakamları

\begin{tabular}{|l|c|c|c|}
\hline ÜLKELER & $\begin{array}{c}\mathbf{2 0 1 3} \\
\mathbf{( 1 0 0 0} \mathbf{D O L A R})\end{array}$ & $\begin{array}{c}\mathbf{2 0 1 4} \\
\mathbf{( 1 0 0 0} \text { DOLAR) }\end{array}$ & $\begin{array}{c}\mathbf{2 0 1 5} \\
\mathbf{( 1 0 0 0} \text { DOLAR) }\end{array}$ \\
\hline 1. Çin & 32.351 .686 & 33.601 .205 & 31.271 .468 \\
\hline 2. Hindistan & 5.102 .277 & 4.973 .318 & 4.781 .775 \\
\hline 3. Pakistan & 3.107 .908 & 3.287 .131 & 3.329 .021 \\
\hline 4. Türkiye & 3.276 .789 & 3.315 .571 & 2.807 .982 \\
\hline 5. Kore & 2.634 .549 & 2.679 .120 & 2.311 .571 \\
\hline 6. Tayvan & 2.266 .131 & 2.343 .813 & 2.243 .238 \\
\hline 7. Almanya & 2.216 .735 & 2.286 .747 & 1.934 .922 \\
\hline 8. İtalya & 1.730 .359 & 1.854 .925 & 1.560 .620 \\
\hline 9. Japonya & 1.301 .148 & 1.251 .849 & 1.185 .788 \\
\hline 10. ABD & 1.011 .193 & 1.073 .202 & 999.082 \\
\hline Dünya & $\mathbf{7 0 . 6 4 8 . 9 3 0}$ & $\mathbf{7 2 . 9 5 0 . 7 2 0}$ & $\mathbf{6 5 . 6 2 9 . 9 7 4}$ \\
\hline
\end{tabular}

Kaynak: www.trademap.org, 2017. 


\subsection{Türkiye’de Ev Tekstili Sektörü}

Dünya pazarında ev tekstili ihracatında ilk sıralarda yer alan Türkiye sektörde önemli bir konumda olmasına rağmen, ev tekstili ihracat hacminde dünyada olduğu gibi küresel kriz ve çevresel faktörlerin etkisi ile belirli yıllarda dalgalanmalar yaşamıştır. Örneğin, söz konusu sektöre ait ihracat hacminde 2009 yılında bir önceki yıla kıyasla yaklaşı \%24'lük, 2015 yılında \%14'lük oranda bir düşüş görülmüştür. Buna rağmen Türkiye'de ev tekstili sektörü, ihracatın hacminin büyümesi ile beraber sürekli gelişmektedir. (T.C. Ekonomi Bakanlığı, 2016:2-4). Günümüzde Türkiye ev tekstili alanında kaliteli, farklılık yaratan ve yenilikçi ürün gruplarına sahip olup, markalaşma konusunda dünyanın sayılı ülkelerinin arasında yer almaktadır (UİB, 2017:3).

Tablo 2'de görüldüğü üzere, Türkiye'de ev tekstili ürünlerinin ihracatı 2015 ve 2016 yıllarında 2,6 milyar dolar iken, 2017 yılında 2,7 milyar dolara yükselmiştir. Ev tekstili ihracatında ürün grubu olarak ilk sırayı havlu alırken, listeyi yatak çarşafları ve perdelik kumaş takip etmektedir.

Tablo 2: Türkiye’nin Ev Tekstili Ürünleri İhracatı (1000\$)

\begin{tabular}{|l|l|l|l|}
\hline ÜRÜN ADI & 2015 FOB USD & 2016 FOB USD & 2017 FOB USD \\
\hline Havlu & 621.741 & 666.836 & 681.974 \\
\hline Yatak çarşafları & 522.961 & 535.506 & 530.533 \\
\hline Perdelik kumaş & 335.592 & 314.545 & 322.301 \\
\hline Diğer ev tekstili & 326.854 & 297.920 & 302.466 \\
\hline Bornoz & 173.261 & 157.936 & 176.746 \\
\hline Diğer mefruşat eşyas1 & 154.666 & 150.668 & 175.705 \\
\hline Döşemelik kumaş & 148.303 & 126.854 & 131.807 \\
\hline $\begin{array}{l}\text { Perdeler, iç storlar, } \\
\text { hazır perde }\end{array}$ & 121.389 & 110.547 & 113.544 \\
\hline $\begin{array}{l}\text { Tüller ve diğer ağ } \\
\text { mensucat }\end{array}$ & 45.693 & 63.736 & 62.442 \\
\hline Örme perde & 50.194 & 52.719 & 52.540 \\
\hline Battaniyeler & 53.729 & 51.386 & 43.535 \\
\hline Dantelalar & 42.188 & 39.175 & 40.621 \\
\hline Masa örtüleri & 34.505 & 34.861 & 34.668 \\
\hline Yatak örtüleri & 29.417 & 30.499 & 33.371 \\
\hline Yastık ve yorganlar & 2.356 & 2.458 & 2.457 \\
\hline Elişi duvar halıları & 62 & 43 & 19 \\
\hline Toplam & $\mathbf{2 . 6 2 2 . 9 1 8}$ & $\mathbf{2 . 6 3 5 . 6 9 1}$ & $\mathbf{2 . 7 0 4 . 4 6 0}$ \\
\hline
\end{tabular}

Kaynak: UiB, 2017

\section{Masa Örtüsü Ürün Grubu}

İşlevsel özelliklere sahip olmasının yanında dekorasyon olarak da kullanılan estetik görüntü taşıyan masa örtüsüne duyulan ihtiyaç, evlerde masanın yemek amaçlı kullanımı ile beraber artmıştır. Keten, pamuk, yün, ipek gibi birçok çeşidi bulunan masa örtüsü, masaları kirlenme, tozlanma, çizilme gibi etkilerden koruma amaçlı kullanılmaktadır (Aybartürk, 2011:1-2).

Tablo 2'de görüldüğü üzere masa örtüsü ihracatının son üç yılının rakamlarındaki değişim \%1'i geçmemektedir. Söz konusu sektör, rekabetin yoğun olduğu ucuz ve hızlı tüketim 
ürünlerin olduğu bir alan olarak tanımlanmaktadır. Müşterilerin beklentileri sadece fiyat-kalite ekseninde şekillenmemektedir, aynı zamanda birçok beklentiyi gerçekleştirmek üzerine kuruludur.

Sektörde faaliyet gösteren işletmeler kendilerini sürekli moda ve desen odaklı yenilemekte ve sektörü dinamik tutmaktadır. Araştırmaya konu olan işletme ev tekstilinin masa örtüsü üretimi konusunda faaliyet göstermekte olup, rekabette söz sahibi olabilmek ve bir adım öne geçebilmek için aşağıdaki konular üzerinde özenle çalışmaktadır;

- Müşteri ihtiyaç ve beklentilerine karşı esnek olabilmek,

- Hizlı servis,

- Modayı ve trendleri yakalamak ve müşterilere sunabilmek,

- Çin'in önüne geçebilmek. Yapılan tasarımların Çin tarafından kopyalanmasını engelleyebilmek için sürekli yeni tasarımlar yapmak,

- Üretimde verimlilik çalışmaları ile daha hızlı servis sunmak, daha esnek olabilmek.

\subsection{PVC Masa Örtüsü ve Üretim Süreci}

Günümüzde PVC masa örtüsünün kullanımı desen seçeneklerinin fazla olması, kullanım kolaylığı, kolay temizlenebilmesi, uzun ömürlü olması, su tutmaması gibi birçok avantajının olması nedeniyle yaygınlaşmaktadır (Aybartürk, 2011:6-7).

PVC masa örtüsünün üretim süreci ile ilgili aşamalar aşağıda yer almaktadır;

1. Kalender Hattı: PVC masa örtüsünün en önemli noktası PVC filminin üretimidir. Kalender hattı, PVC filminin üretildiği hattır. PVC film müssterinin ihtiyacına göre farklı ölçülerde (kalınlık-en) ve farklı renklerde üretilebilmektedir. Filmler jumbo bobin olarak üretilmekte ve ihtiyaç halinde baskı hattına alınabilmek için özel sepetlerde muhafaza edilmektedir.

2. Baskı Hattı: Müşterilerin ilgisini çeken görselliğin elde edildiği bölümdür. Rotogravür bask1 tekniği kullanılarak öncesinde çalışılan tasarımlar silindirlere işletilmektedir. Silindir ile birlikte kullanılacak mürekkeplerin üretimi gerçekleştirilmektedir. Son olarak üzerine baskı yapılacak PVC film kalender hattından alınarak baskı hattına bağlanmaktadır. Müşterinin istediği desene ait silindirler hatta bağlanmaktadır. $\mathrm{Bu}$ silindirlerde kullanılacak mürekkepler baskı hattına getirilip teknelere beslenmektedir. Böylelikle tasarımı yapılmış desenlerin PVC film üzerine transferi gerçekleştirilmektedir. Baskılı jumbo bobin bir sonraki işlemin uygulanabilmesi için sepetler ile laminasyon hattına taşınmaktadır.

3. Laminasyon Hattı: Baskı hattından gelen PVC bobinin arkasına Nonwoven (bez) yapıştırılması işleminin gerçekleştirildiği bölümdür. İhtiyaca göre film yüzeyine kabartı hissi vermek için gofraj işlemi de bu hatta uygulanmaktadır. Üretimi biten masa örtüleri müşteri isteklerine göre farklı metraj ve enlerde rulolara sarılıp, ambalajlanarak sevkiyatı gerçekleştirilmektedir. 


\section{Yöntem}

$\mathrm{Bu}$ araştırmanın amacı, müşteri talebi üzerine üretilen yeni ürünün müşterinin ihtiyaçlarına uygun hale getirmek için geçirdiği üretim sürecini analiz ederek, işletmeye ve müşteriye ne şekilde katma değer sağladığını ortaya koymaktır.

Yazında yer alan araştırmalar kurumsal çerçeve içerisinde incelendiğinde, ev tekstili ve ev tekstili alt ürün grubu olan masa örtüsü ile ilgili yapılan araştırmalarının azlığı dikkat çekmektedir. Bu nedenle, söz konusu araştırmanın yazına katkı sağlayacağı düşünülmektedir. Ayrıca araştırmanın ürün-müşteri ilişkisi konusunda sektöre rehberlik görevi üstleneceği öngörülmektedir.

Araştırmanın yöntemi belirlenirken, nitel araştırma yöntemlerinden olan mülakat yapılmış ve ilgili dokümanlar incelenmiştir. Vaka analizi yöntemi ile yeni ürünün üretim aşamalarına yer verilerek ortaya çıkan sonuçlar değerlendirilmiştir.

\section{Bulgular}

Araştırmaya konu alan işletme, İzmir'de PVC masa örtüsü üreten ve 55'i aşkın ülkeye ihracat yapan 22 yıllık bir firma olarak faaliyetlerini sürdürmektedir. Üretimde teknolojik altyapıyı kullanan, kalite standartlarını uygulayan ve ARGE çalışmalarına büyük önem veren bir işletme olarak müşteri beklentilerini ve pazar taleplerini yakından takip etmekte ve sektörün gelişimine önemli katkılar sağlamaktadır.

Yukarıda anlatıldı̆̆ı üzere işletmede üretilen masa örtülerinin arka tarafına nonwoven lamine edilmekte ve nihai ürün olarak satılmaktadır (Şekil 1). Müşteriden gelen talebe göre PVC filmin her iki tarafına da ayrı ayrı baskı yapılması talebi gelmiştir. Bu durumda müşteri ürüne nonwoven lamine edilmesini tercih etmemektedir (Şekil 2). Müşterinin pazara sunmak istediği bu yeni ürünün düşük fiyatlı olması (nonwoven laminasyon maliyetinin bulunmamasından dolayı) ve son tüketicide bir ürün ile iki farklı ürüne sahip olma algısını yaratması nedeniyle ürüne olan ilginin artacağı tahmin edilmektedir.
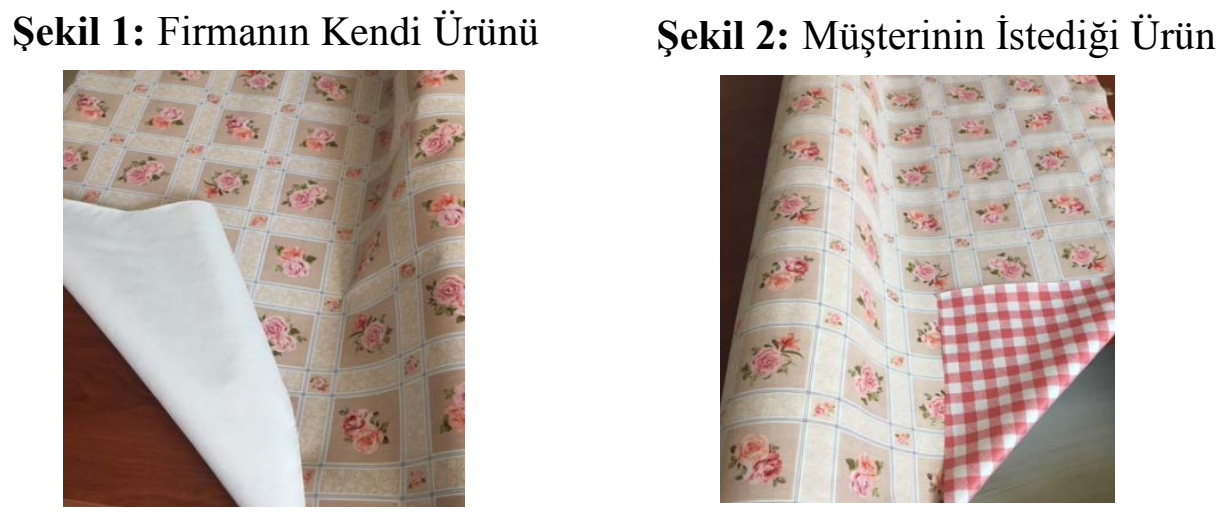

Ürün müşteri açısından avantajı olmasına rağmen, işletme için mevcut şartlar altında ürün üretilip rulolara sarıldığında her iki yüzeyinde de baskı olduğundan yapışmaktadır. Bu şartlar altında ürün ticarileştirilememektedir.

İşletme mevcut durumdaki ürünün müşteri beklentilerine uygunluğunu anlamak için laboratuvar çalışmalarına başlayıp mevcut durumun fotoğrafını çekerek görselleştirmiştir. 
Sonrasında müşterinin ihtiyaç ve beklentileri karşılayabilmek adına işletme iyileştirme çalışmalarını başlatmıştır.

Mevcut şartlar ve formülasyon ile PVC filme çift taraflı baskı yapılıp numuneler 24 saat boyunca 70 'C'de ağırlık altında bekletilmiştir (Şekil 3). Sonrasında numunelerde varsa eğer yapışmaları ölçmek için çekme kopma testleri yapılmıştır.

Şekil 3: Mevcut Durum Numune

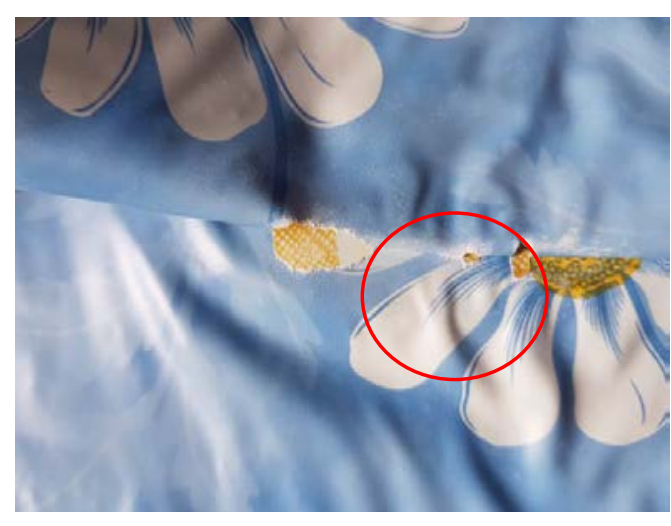

Mevcut durumu anlamak için 10 numuneye yapılan çekme kopma sonucuna göre bu şartlarda ürünlerin yapıştığı görülmüştür (Şekil 4). Yapışan ürünler ortalama 5,75 newtonluk bir kuvvete karşı koyacak kadar yapışmakta, sonrasında da yırtılarak kopmaktadır. Şekil 3 'te mevcut durumu anlatan numune görseli bulunmaktadır. Bu şartlarda üretilen ruloların müşteriye ulaştığında açılmayıp yapışacağı tahmin edilmektedir.

Şekil 4: Mevcut Durum Çekme Kopma sonuçları

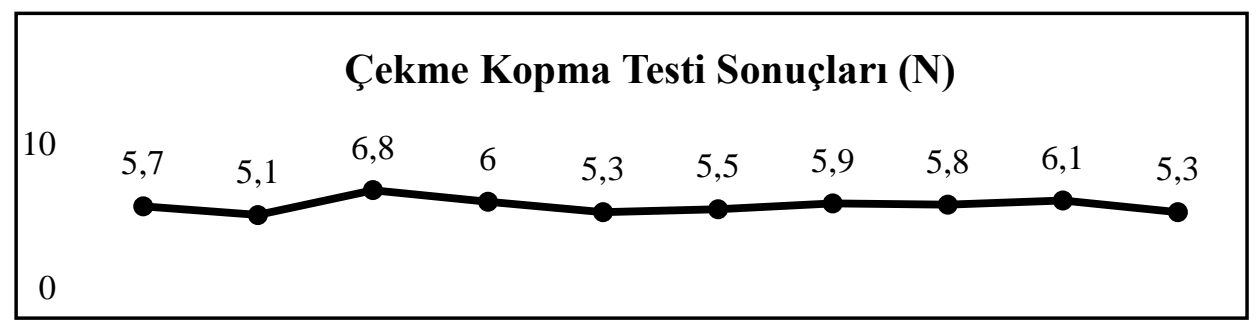

Mevcut durumda oluşan yapışma problemini aşmak için deneme 1 alternatif anti-block ajanı yöntemi uygulanmış olup, mürekkep yapımında kullanılan reçine formülünde değişikliğe gidilmiştir. Formülde bulunan antiblock katkı ajanı yerine alternatif hammadde araştırmaları gerçekleştirilmiştir. Sonuç veren alternatif hammadde ile yeni reçine çalışılmıştır. Bu reçine ile yapılan mürekkepler ile deneme aynı şartlarda tekrarlanmış (Şekil 5) ve numunelere çekme kopma testleri tekrardan yapılmıştır. 
Şekil 5: Deneme 1 Numune Görseli

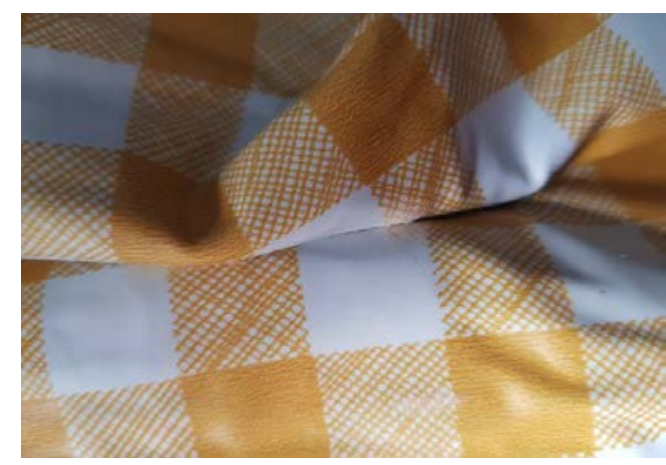

Yeni formülasyon ile alınan numunelere aynı şartlarda aynı test yöntemi uygulanmış ve hala yapıştı̆̆ 1 görülmüştür. Fakat bu kez elde edilen numunelerin kopma kuvveti ortalama 3,3 newtona kadar gerilemiştir (Şekil 6). Gelişme kaydedilmekle birlikte, henüz müşteri isteği karşılanmamıştır. Denemede kullanılan anti-block ajanı muadil hammadde niteliğinde olduğundan ürün maliyetine etkisi olmamıştır.

Şekil 6: Deneme 1 Çekme Kopma Sonuçları

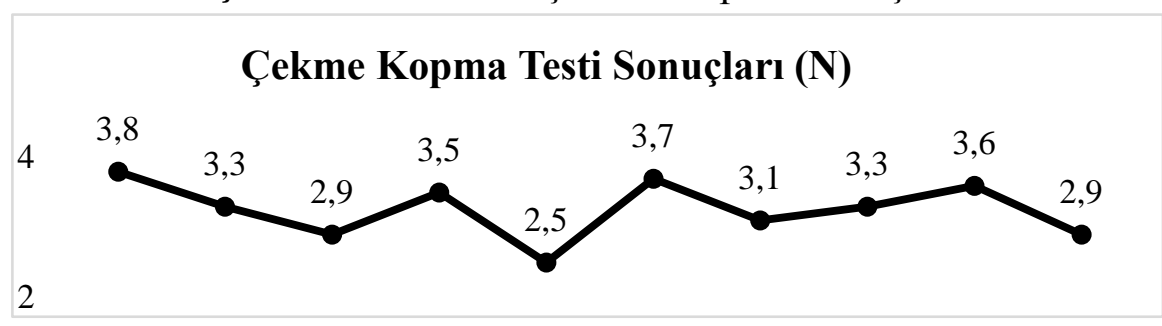

Alternatif anti-block ajanı içeren formül yeterli olmadığından baskı üzerine deneme 2 üst lak uygulaması bir diğer deyişle, bariyer amaçlı coating uygulaması yapılmıştır (Şekil 7). Elde edilen numunelere aynı şartlarda aynı testler uygulanmıştır.

Şekil 7: Deneme 2 Numune Görseli

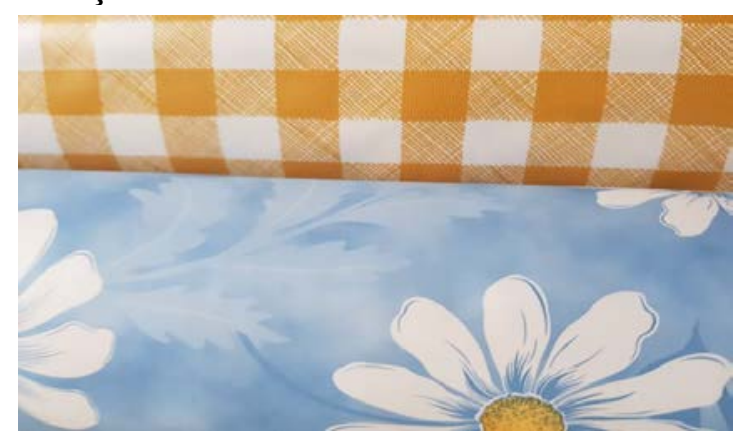

Yapılan testler sonucunda numuneler çekme kopma testinde ortalama 0,09 newtonluk bir direnç göstererek rahatlıkla ayrılmışlardır (Şekil 8). Ortaya çıkan sonuç ile müşteriye ürün gönderilmeden önce gerekli aksiyonlar alınıp işletme tarafından sorun çözülmüştür. 
Şekil 8: Deneme 2 Ceekme Kopma Sonuçları

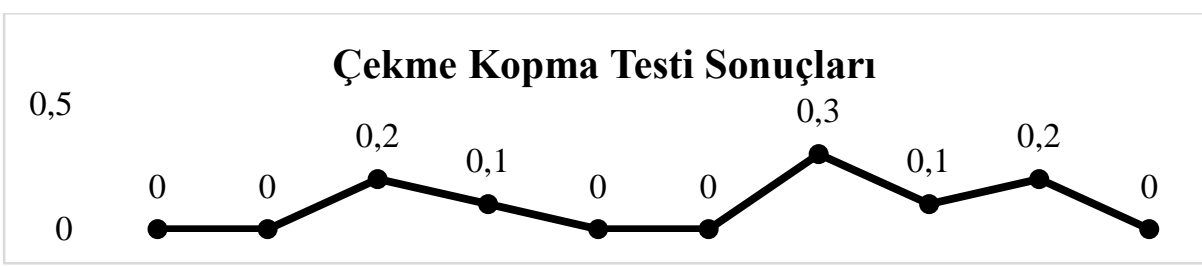

Bir önceki denemede çift taraflı ürünün ruloya sarım esnasında baskılı yüzeylerin birbirine temas etmemesi ve bu sebepten dolayı yapışmasını engellemek adına baskılı yüzeyler arasında bariyer olması için üst lak uygulaması yapılmıştır. Fakat bariyer olması için uygulanan üst lakın hedef ürüne maliyet yüklemesi beklenmektedir. Bu bakımdan ürünün fiyat anlamında müşteri beklentilerini karşılamayabileceği tahmin edilmektedir. Bu duruma da alternatif olması açısından yeni bir yöntem geliştirilmiştir. Deneme 2 tekrarlanmış ve elde edilen çift taraflı ürüne gofraj uygulaması yapılarak aynı şartlarda aynı testlere tabi tutulmuştur (Şekil 9).

Şekil 9: Deneme 3 Numune Görseli

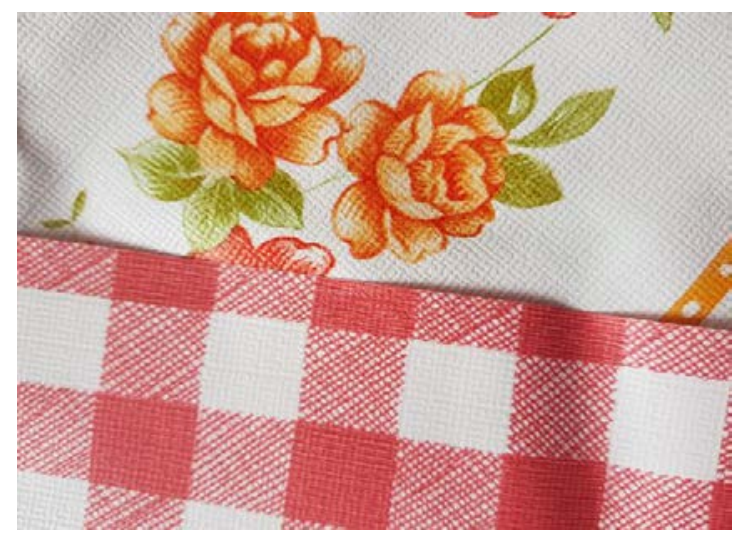

Şekil 10: Deneme 3 Numune Çekme Kopma Sonuçları

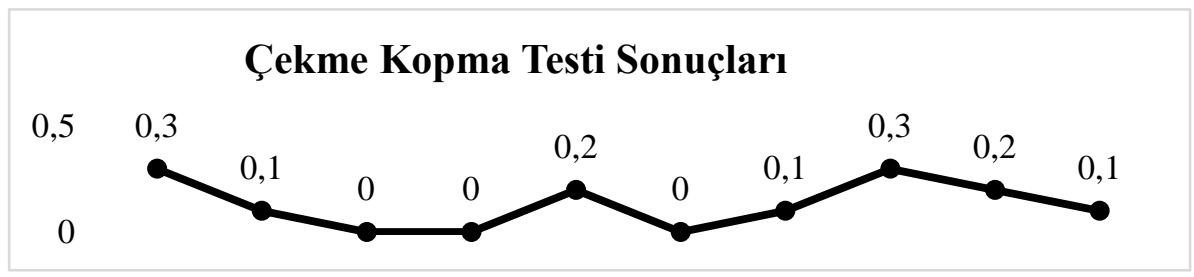

Çekme kopma testinde numuneler ortalama 0,13 newtonluk bir direnç göstererek rahatlıkla ayrılmışlardır (Şekil 10). Bu deneme ile müşteri beklentisi hem ürün hem de maliyet anlamında karşılanmıştır. Yapılan gofraj uygulaması ile ruloya sarılan ürünün baskılı her iki yüzeyi arasındaki temas yüzeyi azaltılarak yapışma engellenmiştir. 
Șekil 11: Deneme 3 Elektron Mikroskobu

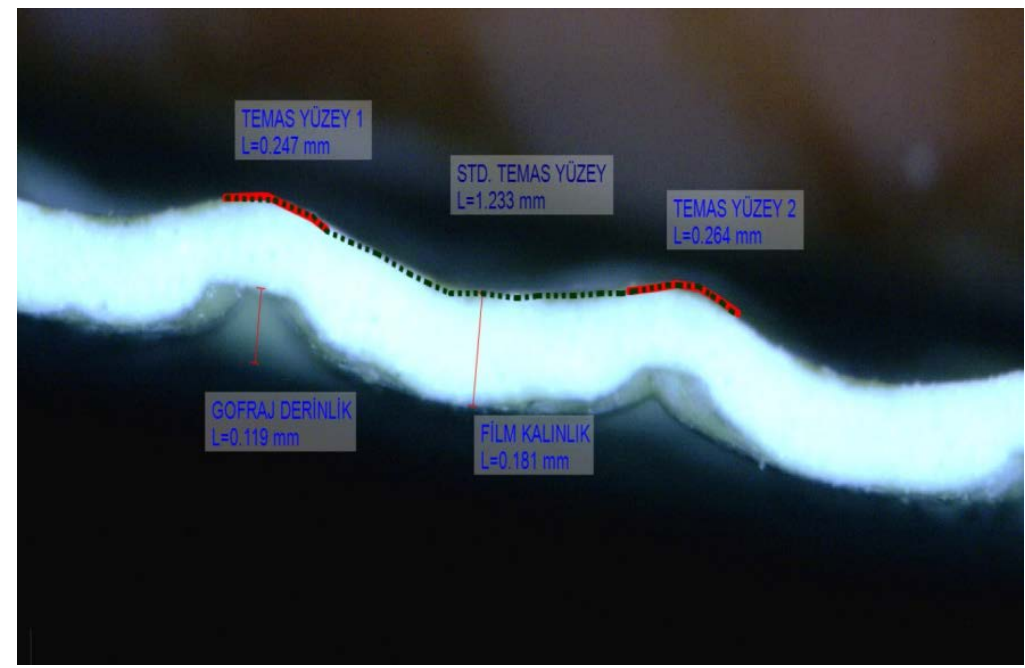

Şekil 11'de de görüleceği üzere numuneye gofraj yapıldıktan sonra temas yüzeyi $\% 60$ civarında azaltılmıştır. Ürüne gofraj yapılmadığı takdirde oluşacak temas yüzeyi STD. TEMAS YÜZEY (STANDART TEMAS YÜZEY) olarak Şekil 11'e eklenmiştir (1,233 mm). Gofraj sonrasında oluşan derinlik farklarından dolayı aynı yüzeyde temas noktası ikiye inmiş ve toplam temas yüzeyi 0,511 mm (TEMAS YÜZEY 1+ TEMAS YÜZEY 2) ye düşürülmüştür. Böylelikle sarılan rulolarda yaşanan yapışma probleminin önüne geçilmiştir.

Son denemeden sonra elde edilen ürün, hem fiyat hem de ürün çeşidi olarak müşterinin beklentilerini karşılamıştır. Ürünün müşteriye teslimatı yapıldıktan sonra, işletmeye müşteri tarafından olumlu geri bildirim verilmiştir. Ürünün satışları halen artarak devam etmektedir.

\section{Sonuç ve Tartışma}

Ev tekstilinin araştırmaya müsait ve yeniliklere açık bir sektör olduğu bilinmektedir. $\mathrm{Bu}$ nedenle sektörde yeni teknolojiler ve özel tasarımlar kullanılarak ürünlerin performansları artırılmaktadır. Anti bakteriyel yatak çarşafları, 1sı ayarlı perdeler vb. ürünler sektörde yapılan yeniliklere örnek gösterilebilir (Marmaralı vd., 2009).

Tüketiciye doğru çözümler sunmak amacıyla tüketicinin psikolojisini anlamak, teknoloji ile modayı bütünleştirmek önemlidir (Das, 2010:3). Örneğin, masa örtüsü renginin yemek yerken bireyin ögüüünü artırmada etkin bir rol üstlendiği, bununla birlikte, dekorasyon stilini ve atmosferi de etkileyebildiği görülmektedir (Tomita vd., 2006). Bununla birlikte sadece masa örtüsünün renginin değil, tasarım ve kalitesinin de müşteri memnuniyeti artırmada etkili olduğunu belirten araştırmalar da mevcuttur (Kim, 2006:571).

Müşteri memnuniyetinin en önemli kaynağı müşteri beklentilerini anlamaktır. Müşterinin beklentisi, kullanım alışkanlığına uygun üretilecek yeni ürünün fiyat açısından tatmin ederek satışlarını artırması üzerinedir. Söz konusu araştırma, yazındaki araştırmaları destekler nitelikte olup, müşteri beklentilerini karşılamak amacı ile işletmenin tasarım merkezine ait ürün geliştirme projesi kapsamında yapılmıştır.

Müşterinin talebi işletmeye geldikten sonra yeni ürünün üretilebilirliğine ilişkin yapılan üretim çalışmaları sonucunda, ürünün yapışma problemi tespit edilerek ürünle ilgili farklı süreçler uygulanarak denemeler yapılmıştır. Birinci denemede alternatif anti-block ajanı 
uygulanmış, fakat yapışma sorunu çözülememiştir. İkinci denemede üst lak uygulaması yapılmış ve yapışma sorunu çözülmüştür. Fakat, üst lak ürüne ek bir maliyet getirdiğinden fiyat anlamında müşterinin tatmin olmayacağı düşünülmektedir. $\mathrm{Bu}$ nedenle, yeni bir yöntem geliştirilmiştir. İkinci deneme tekrarlanarak, elde edilen mevcut ürüne gofraj uygulaması yapılmıştır. Yapılan bu uygulama ile beraber, ruloya sarılan ürünün baskılı her iki yüzeyi arasında temas azaltılmış ve yapışma engellenmiştir. Böylece son denemeden sonra elde edilen ürün, müşterinin isteğine uygunluk göstermektedir.

Araştırmanın sonuçlarına göre ürün işletmeye rekabette artı puan kazandırmıştır. Müşteri beklentisi hem ürün hem de ürün maliyeti bazında karşılanmıştır. Geliştirilen yeni üründen işletmenin satış anlamında beklentisi karşılanmıştır. Satışların hem yeni ürün sebebiyle artması hem de yeni pazarlara girme imkânı elde edileceğinden mevcut ürünün de satışlarını artırması beklenmektedir. Aynı zamanda müşteri beklentilerine yönelik yapılacak çalışmalar ile müşterilerin işletmeye olan bağlılığı da artacaktır. Sonuç olarak yeni ürün hem müşteriye hem de işletmeye katma değer sağlamıştır.

\section{Kaynakça}

Ama Research. (2016). Household Textiles Market Reports-UK 2016-2020 Analysis. Retrieved from https://www.amaresearch.co.uk/products/household-textiles-2016. (Erişim Tarihi:03.05.2018)

Aybartürk, B. (2011). “Cad/Cam Tasarımından Üretim Aşamasına PVC Masa Örtüsü'” (Yüksek Lisans Tezi), İzmir: Dokuz Eylül Üniversitesi, Güzel Sanatlar Enstitüsü, Tekstil ve Moda Tasarımı Anabilim Dalı.

Das, S. (2010). Performance of home textiles. India:WPI Publishing,

Durur, G. \& Parer, O. (2009). “'Türkiye ve Denizli'de Ev Tekstillerine Genel Bir Bakış’, Tekstil ve Mühendis, 16 (76), 17-23.

Güney Ege Kalkınma Ajansı (GEKA). (2015). Denizli Ev Tekstil Sektörü Analiz Raporu. Retrieved from http://geka.gov.tr/2460/denizli-ev-tekstil-sektoru-analiz-raporu-2015

Holmsten-Carrizo, C. (2013). "Responsible sourcing and transparency in the home textile industry” (Master Thesis), Sweden: Swedish University of Agricultural Sciences, Environmental Economics and Management, Master’s Programme.

Kılıç, A. G. S., Özdemir, A. G. D. E., \& Şenol, A. G. D. G. (2011). “Küresel ekonomik kriz ve ev tekstil sektörü: Pazarlama bakış açısından yöneticilerin değerlendirmeleri’', Paradoks: The Journal of Economics, Sociology \& Politics, 7(1), 67-80.

Kim, S. H. (2006). " A study on the customer's satisfaction of the tableware on foodstyling using fuzzy cognitive maps"', Journal of the Korean Society of Food Culture, 21(6), 571576.

Marmaralı, A., Armakan Mecit, D., Oğlakçıŏlu, N. (2009). “Ev tekstilleri’”, Standard, 563 (48),18-23.

Ozgur, H. (2005). Integration of a local economy to the global and European markets through export-led growth and specialized textile products export: Home textile production in Denizli, Turkey. Proceedings of the 18th European advanced studies institute in regional science in Lodz-Cracow, Poland.

Pothault, M. (1997). The Book Of Fine Linen. Italy:Thames And Hudson. 
Taylor, M.C. (1972). Technology of Textile Properties. London:Billing \& Sons Ltd.

Trade Map.(2017). http://www.trademap.org, (Erişim Tarihi:03.05.2018).

Tomita, K., Ono, M. \& Kimiko, T. A. (2006). "The atmosphere of the dining produced by the various kinds of tablecloth colors under three kinds of illuminant condition', Journal of ARAHE, 13,173-184.

Türkiye Cumhuriyeti (T.C.) Ekonomi Bakanlığı.(2016). Ev Tekstili Sektör Raporu. İhracat Genel Müdürlüğü, Tekstil ve Konfeksiyon Ürünleri Daire Başkanlığı. Erişim yeri https:/www.ekonomi.gov.tr/portal/content/conn/UCM/uuid/dDocName:EK-224569

Uludağ İhracatçı Birlikleri (UİB). (2017). Ev tekstili Raporu (Ar-Ge Şubesi). Erişim yeri http://www.uib.org.tr/tr/elektronik-kutuphane.html?t=Ar-Ge\%2CRaporlar\%2CTekstil

Wagner, J. (1986). “Expenditures for household textiles and textile home furnishings: an Engel curve analysis”, Family and Consumer Sciences Research Journal, 15(1), 21-31. 


\section{EXTENDED ABSTRACT}

\section{Meeting Customer Demands Under Global Competitive Dynamics: A Review of PVC Tablecloth Sector}

With the effects created by the globalization phenomenon in recent years, intensified global competition has set the stage for significant changes in the world. At this point, it is inevitable for business to accept and adapt the innovations brought about by changes, keep up with the pace of change and follow the external environment constantly, and efforts to survive in the world of change have to take appropriate steps in the direction of being different.

Businesses which have embraced innovation and change and are committed to providing quality customer-focused services, have made significant progress against their competitors. Businesses which want to have a premise in the competitive environment give preference to $R \& D$ and $P \& D$ units and direct their investments to these units in order to produce new products suitable for the customer's needs. These new products offered by the businesses are preferred by the customers and provide added value to the business as sales, profitability and growth.

This research is about product differentiation in the subgroup of home textile sector as table cloths and reflecting on customer and business. The aim of the research is to analyze how the new product produced on the customer's request is adapted to the needs of the customer and to show how the business and the customer provide added value.

After an overview of the home textiles sector in the first part of the research conducted in this framework, information is provided on the tablecloth product group and PVC tablecloth production process. In the second part, the production process of the new product produced in line with the customer's wishes is explained by making case analysis. In the last section, the results of the research are discussed and the added value that this product has provided to operate within the competitive environment is mentioned.

According to the result of the research, customer satisfaction has been provided with product differentiation, which is reflected as sales to the business and customer loyalty.

In the literature, there is lack of research about this subject and relationship of variables. So, it is forecasted that the research will contribute the literature. It is also envisaged that the sector will have guidance on product-customer relationship. 